\title{
FACTORS RELATED TO ADOLESCENT DELAY IN PANEMBONG GIRANG CIANJUR
}

\author{
By \\ Helvy Yunida \\ Widyaiswara ahli Madya Balai Besar Pelatihan Kesehatan Ciloto Indonesia \\ Email: hybindjaji@gmail.com
}

\begin{tabular}{l}
\hline \hline Article Info \\
\hline Article history: \\
Received July 9, 2021 \\
Revised August 20, 2021 \\
Accepted Sept 11, 2021
\end{tabular}

Keywords:

Factors; Juvenile Delinquency, Panembong Girang

\begin{abstract}
The juvenile delinquency rate in Panembong girang has long been very high. The environment is not good. For parents who have teenagers, they will be very worried if their teenagers are released to hang out with teenagers in such an environment. Many behaviors that lead to juvenile delinquency. The teenager's acquaintance with the Panembong Girang teenager has led to a legal case, which has ended at the court. These include being involved in drug abuse, beating other people until they are seriously injured and sentenced to prison, drinking alcohol, promiscuity, stealing, and others. The impact of juvenile delinquency The juvenile mortality rate in Panembong Girang is very high, compared to the death rate of adults and parents. The cause of the high mortality rate of adolescents in Panembong girang indirectly is the lack of control of adolescents in managing themselves. Often gather, in groups with peers, who incidentally have bad behavior. So that teenagers do what they should not do. Having an uncontrollable personality, causing the teenager to fall into drinking liquor or alcohol. One of the causes of death in adolescents worldwide due to accidents. in Panembong Girang the number of causes of death for adolescents is directly due to alcohol and accidents. The purpose of the study was to determine the cause of death of adolescents and to determine the lifestyle of panembong happy adolescents. The research method is a qualitative descriptive research design. The informants were taken by 3 neighbors next door to the meatball seller's house, teenagers and members of the Youth Organization. Results and Discussion: the cause of the death rate of adolescents due to alcohol died immediately and when drunk driving a motor vehicle an accident. Conclusion: the factors of the high mortality rate of adolescents in Panembong Girang are due to alcohol and accidents after drinking alcohol
\end{abstract}

This is an open access article under the CC BY-SA license.

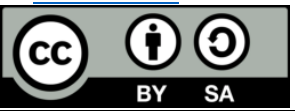

\section{Corresponding Author: \\ Helvy Yunida \\ Widyaiswara ahli Madya Balai Besar Pelatihan Kesehatan Ciloto Indonesia \\ Email: hybindjaji@gmail.com}

\section{INTRODUCTION}

The juvenile delinquency rate in Panembong has long been very high. The environment is not good. For parents who have teenagers, they will be very worried if their teenagers are released to hang out with these teenagers. Many behaviors that lead to juvenile delinquency. The juvenile delinquency committed by the Panembong Girang teenager has led to a legal case, which has ended at the court. These include being involved in drug abuse, beating other people until they are seriously injured and sentenced to prison, drinking alcohol, promiscuity, stealing, and others. The longterm impact of juvenile delinquency causes a high juvenile mortality rate in Panembong Girang, compared to the death rate for adults and the elderly. The cause of the high mortality rate of adolescents in Panembong girang indirectly is starting from the lack of control of adolescents in managing themselves. So that teenagers do what they should not do. Having an uncontrolled personality, causes the teenager to enter into several types of juvenile delinquency, including falling into drinking liquor or alcohol.

According to Infodatin, adolescence is a period of rapid growth and development both physically, psychologically and intellectually. The typical nature of adolescents is to have a great curiosity, like adventure and 
challenges and tend to dare to take risks for their actions without being preceded by careful consideration. If the decisions made in dealing with conflict are not right, they will fall into risky behavior and may have to bear short and long term consequences in various physical and psychosocial health problems. The nature and risk behavior of adolescents requires the availability of adolescent health care services that can meet the health needs of adolescents, including services for reproductive health. ${ }^{1}$ According to infodatin, the adolescent reproductive health program is integrated into the youth health program in Indonesia. Since 2003, the Ministry of Health has developed a health service model called the Youth Reproductive Health Service (PKPR). PKPR is closely related to the school health business activities (UKS) which are also fostered by the local Puskesmas. The PKPR program is very suitable to be given in the village of Panembong Girang, Cianjur, in order to get counseling services and increase the ability of teenagers to apply education and healthy life skills (PKHS). Drinking liquor is one of the bad habits of teenagers in this era. This behavior can kill a teenager directly. With a lack of economic conditions and a low level of education, these teenagers are easily influenced by their teenage friends to join the drinking. The solution to channeling that desire is to drink cheap, cheap oplosan to be an option. Though the drink is very deadly if drunk by the teenager. The proof is that many teenagers died after drinking alcohol, including teenagers from Panembong Girang village.

Drinking liquor is one of the bad habits of teenagers in this era. This behavior can kill a teenager directly. With a lack of economic conditions and a low level of education, these teenagers are easily influenced by their teenage friends to join the drinking. The solution to channeling that desire is to drink cheap, cheap oplosan to be an option. Though the drink is very deadly if drunk by the teenager. The proof is that many teenagers died after drinking alcohol, including teenagers from Panembong Girang village. A teenager in Tangerang sub-district died after an adulterated liquor party. One victim died that same night, while four others died the next day. That night, a group of 20 young people gathered in front of the shop, playing guitar. As a result of the incident, five teenagers died and one person was in critical condition, and 14 others were being identified. The death rate due to adulterated drinks in Indonesia or on a national scale, since January 2008 - April 10, 2018 the death rate is 840 and 521 treated. ${ }^{2}$ The death rate in 2018 reached 57 cases, more than the total death rate for the previous five years (2013-2017). Indonesian Policy Studies (CIPS) stated that the number of deaths due to consumption of adulterated alcoholic beverages or bootleg liquor for the 20142018 period was very high in various regions in Indonesia. During that period, CIPS recorded that around 546 people died due to the consumption of bootleg liquor. the number increased sharply, doubling from the 2008-2013 period. Based on CIPS data, during that period as many as 232 died because of the bootleg drink. ${ }^{3}$

In Bandung, West Java, there is one death for every 615,000 people per year due to illegal alcohol consumption. This number is 5 times higher than the national average of one death per 3 million people per year. This was revealed during the launch of research and Public Discussion on Illegal Alcohol, underage consumption and its threat to health. According to CIPS researchers Hizkis Respatiadi and Sugianto Tandra, the volume of alcohol consumed by Indonesians is not a problem, because they drink much less than residents of other countries. According to data from the World Health Organization, Indonesians only consume 0.6 liters of pure alcohol per capita per year. This is lower than the average of other Southeast Asian countries which reached 3.4 liters or Arab countries 0.7 per liter. The problem is that what is consumed contains ingredients that are not suitable for consumption, such as mosquito repellent, headache pills, battery fluids to spirit fluids. It is evident from the consumption of 0.6 liters of alcohol, only 0.1 liters of legal alcohol are consumed. According to data on 40 deaths caused by adulterated alcohol between January 2008December 2013. The number has more than doubled and reached 90 cases in January 2014-April 2018. The total number of deaths was 130 and 55 were treated for drinking adulterated alcohol. ${ }^{4}$ The Cianjur Police Narcotics Investigation Unit revealed a case of the circulation of roso-roso liquor. The perpetrators were responded to and 600 plastic bags of Roso-Roso's liquor were ready to be confiscated. The disclosure of this case came from public information that in Sukanagalih Village, Cilaku District, Cianjur Regency, there was a suspicious activity in one of the residents' houses. Then find out the information. It turned out that the information was true that in Sukanagalih village, Cilaku district, Cianjur district, had produced the illegal goods. Finally the place was raided by personnel from the Cianjur police drug unit led by IPTU Ali Jupri et al. There were 5 people who drank liquor, 3 of them died. They come from Cibodas village, Karangwangi village, Ciranjang sub-district. The local government needs to intervene to nurture the youth. Among them is the PKPR program. According to infodatin, the adolescent reproductive health program is integrated into the youth health program in Indonesia. Since 2003, the Ministry of Health has developed a health service model called the Youth Reproductive Health Service (PKPR). The hallmark of adolescent reproductive health services is counseling and improvement services. ${ }^{5}$

the ability of adolescents to apply education and healthy life skills (PKHS). It is hoped that with the implementation of this program, the happy panembong youth can be helped. Panembong Girang is an area of RW 04 which is part of the Mekarsari Village area, Cianjur District, Cianjur Regency. The location of this happy village is approximately $1-2 \mathrm{~km}$ from the city center such as: malls, access to education, markets and others. The education level of the natives born in Panembong Girang is relatively low. There are still few who can get to college. Many young 
International Journal of Social Science (IJSS)

Vol.1 No.3 October 2021, pp:151-158

ISSN: ISSN: 2798-3463 (Printed) | 2798-4079 (Online)

DOI: https://doi.org/10.53625/ijss.v1i3.407

panembong boys are unemployed. Even if there are people who work, they work odd jobs or work in a shop. So that among those who are unemployed, their activities are parking attendants. They took turns in groups as parking attendants on the road leading to the gate to Panembong Girang. Researchers several times saw that some of them were drunk. Even once one night passed by where they gathered, there was a drunk half unconscious sleeping beside the parking lot. According to data from an informant, the mortality rate of teenagers in Panembong Girang is very high, more than 10 people in the last 5 years have died suddenly. In 2021, 2 teenagers have died due to alcohol and accidents. It turned out that the number of juvenile deaths had also caught the attention of other neighbors who mentioned and counted on their fingers the number of teenagers who died in this village due to alcohol and accidents. There was an informant who stated that some of the teenagers who died were due to an accident while driving a motorbike while drunk. There are also those who died while drunk. There was even one of the victims, one of whom was a woman. So based on the data and facts that occurred, the researcher is interested in re-examining in the same place with a different title, namely: "Factors related to juvenile delinquency in Panembong Girang Cianjur."

Problem Formulation

What are the factors related to juvenile delinquency in Panembong Girang, Cianjur?

RESEARCH OBJECTIVES

1. General Objective: To find out the factors related to juvenile delinquency in Panembong Girang, Cianjur

2. Special purpose:

- Knowing the cause of the high number of adolescent deaths in Panembong Girang, Cianjur

- Knowing the lifestyle of teenagers in Panembong Girang, Cianjur

\section{LITERATURE REVIEW}

1. Teenagers Definition of teenager The definition of adolescents according to WHO is the population in the age range of 10-19 years, while according to the Minister of Health of the Republic of Indonesia Number 25 of 2014 is the population in the age range of 10-18 years and according to the National Population and Family Planning Agency $(\mathrm{BKKBN})$ the age range of adolescents is 10-24 years. and not married.

2. Teen death the most common causes of death among adolescents worldwide: Accidents, lower respiratory tract infections, suicide, diarrhea, drowning, while according to the NEWS coil, the 3 causes of death in adolescents are: traffic accidents, respiratory infections and suicide deaths every 615,000 people per year due to illegal alcohol consumption in the Greater Bandung area.

\section{RESEARCH METHODS}

The research location is in Panembong Girang Village, Mekarsari Village, Cianjur, while the time of the study was carried out in July 2021. The research population was the Panembong Girang community in RW 4 while the research sample was 3 informants from the Panembong Girang community. What is meant by population according to Sugiyono (2003:90) is a generalization area consisting of objects/subjects that have certain qualities and characteristics determined by researchers to study and draw conclusions. ${ }^{6}$ Meanwhile, according to Sukandarrumidi (2012: 50) the sample is: "part of the population that has the same properties as the object that is the source of the data. ${ }^{7}$ The design or design of this study was carried out in a qualitative descriptive manner. The respondents were 3 informants. The main informant is one person, namely a meatball seller who lives next door to the house. Researchers will dig up information from several informants. One of the informants is a young woman who lives in Panembong Girang village and the other is a member of the Cianjur Panembong Girang Youth Organization. According to Sugiyono (2019-18: ) qualitative research is: "research methods based on post-positivism philosophy, used to examine the condition of natural objects, where the researcher is the key instrument. ${ }^{8}$ while the descriptive research design according to Setiawan Ari S (2011: 84) is: "researchers only describe / describe certain variables in a study without looking for relationships between variables. ${ }^{9}$ Other data collection is done by observation (observation). Observations or observations according to Notoajmodjo Sukijo (2005:93) are: "a result of the soul's actions actively and attentively to be aware of the stimulus. At first, the stimulus from outside hits the senses, and there is sensing, then when the stimulus attracts attention, it will be followed by observation. ${ }^{10}$

\section{RESULTS AND DISCUSSION}

The juvenile delinquency rate in Panembong has long been very high. The environment is not good. For parents who have teenagers, of course, they will be very worried, if their teenagers are released to hang out with Panembong Girang teenagers. Many behaviors that lead to juvenile delinquency. Many juvenile delinquencies committed by Panembong Girang teenagers ended up at the court. These include being involved in drugs, beating others until they are seriously ill, drinking alcohol, promiscuity, stealing and others. The impact of juvenile delinquency that has long 
been causing the high Adolescent Mortality Rate in Panembong Girang. Compared to the mortality rate for adults and the elderly, the mortality rate for adolescents is much higher. The cause of the high mortality rate of adolescents in Panembong girang, indirectly is the lack of control of adolescents in managing themselves. This is probably due to the low level of education, low socioeconomic status, low level of parental education, coupled with an unfavorable environment, making the teenager's relationship less good. Adolescence is a period of transition from child to adult. The teenager physically with a body like an adult can be said to be big, but mentally not ready. Among them do not have the skills to be ready to work, do not have income, are still financed by their parents, and so on. So there is a gap between physical size and mental immaturity. Inequality affects the psychology of the teenager. Adolescence is also a period of transition from childhood to adulthood. So there are gaps that make the teenagers behave in various ways. In addition, adolescence is a time of searching for self-identity. Find out who you are. when his curiosity is high, hanging out with the wrong people, the teenager eventually becomes the wrong association. The unfavorable environment of panembong glee will make teenagers quickly influenced and follow their community. Because making friends for teenagers is the first recognition in social life. Sometimes following his friends' activities, is the beginning of a sense of solidarity as a friend. But over time the influence of his friends will become accustomed to being followed. Eventually, the teenager's behavior was the same as his friend. If his friends are good, the teenager will be good, if he hangs out with the naughty, that's where the teenager starts to become naughty too. As long as this cannot be controlled, over time it will become a habit. Already comfortable with the new habit. The new habit will eventually change into daily behavior, then later it will change into character. If it has become a permanent character, it will be difficult to change it. What's more, if you can't control yourself and then your parents don't control you, the consequences will be very fatal. The bad effects that are happening now are the seeds of past actions. Finally it was too late. The teenager had already gone further. do what it is not supposed to do. It is no longer possible to distinguish between what is good and what is not. Having an uncontrollable personality, causes the teenager to fall into juvenile delinquency which is against the law. drinking liquor which is better known as alcohol. If caught, they will face the law. According to Santrock (2003) in Riga, that juvenile delinquency is a significant increase which is a collection of various behaviors in recent years. ${ }^{11}$ This can be seen from the socially unacceptable facts reported by the National Commission to the occurrence of criminal acts. Meanwhile, according to Suci Prasasti (2017): juvenile delinquency is caused by internal factors and external factors. The causes of these internal factors occur within the individual itself which takes place through a process of erroneous self-internalization in solving the surrounding problems and all influences that come from outside, including: personality, gender and position in the family/community and the causes of external factors, namely: from the outside (external) are things that encourage the emergence of juvenile delinquency that comes from outside the teenager's personal self, namely the surrounding environment including the family, school and community environment. It can be concluded that if the internal and external factors can be balanced and aligned within the youth, juvenile delinquency will not occur and will produce a quality next generation. If teenagers fail to identify themselves, then that's where juvenile delinquency occurs. ${ }^{12}$

The Adolescent Mortality Rate in Panembong Girang is very high, compared to the death rate for adults and the elderly. The cause of the high mortality rate of adolescents in Panembong girang indirectly is the lack of control of adolescents in managing themselves. So that teenagers do what they should not do. Having an uncontrollable personality, causing the teenager to fall into drinking liquor, the term is better known as alcohol. The cause of the high mortality rate for adolescents in Panembong Girang Cianjur decreased by informants and based on observations it was caused by drinking alcohol, in relatively large quantities, causing death. The teenager died directly at home. When he was very drunk, there was someone who, when he was very drunk, was taken to the hospital, and died in the hospital. Some were treated in the hospital for a few days but in the end they couldn't help. There is also a death. When drunk on the highway riding his own motorbike, his motorbike was hit by another vehicle. One of the informants gave the term that the deceased was still a bachelor. Meanwhile, according to WHO data that one of the causes of adolescent death is due to accidents. Similar to the incident of teenagers in Panembong girang, most of them died due to accidents, although there was a triggering cause, namely drinking alcohol first. According to WHO records, in 2015 road accidents were the leading cause of death for adolescents aged 10-19 years. Total WHO data shows that there are 115,000 teenagers killed on the road, the most in the age range 15-19 years. Most of the teenagers who died on the streets were pedestrians, cyclists and motorcyclists. However, this does not happen in all countries. ${ }^{13}$

The results of the researchers' observations a few months back, about the lifestyle of the happy Panembong teenager varied. There's a bunch of drinkers, but during the covid pandemic it's not too flashy. some have a sporting lifestyle. Approaching the month of August, teenagers start to do sports. Together, there is a group of intelligent teenagers. Do not leave the house with school or college activities. According to the World Health Organization WHO admits that they have missed in analyzing the behavior of adolescents. whereas adolescence is a very vulnerable phase for adolescents physically and mentally in human life. Thousands of teenagers die every year. According to Kate Strong, a WHO epidemiologist, so far only focused on the health of infants and children, but recently, WHO has begun 
International Journal of Social Science (IJSS)

Vol.1 No.3 October 2021, pp:151-158

ISSN: ISSN: 2798-3463 (Printed) | 2798-4079 (Online)

DOI: https://doi.org/10.53625/ijss.v1i3.407

to pay attention to adolescents, because the adolescent mortality rate is also very high. ${ }^{14}$ Meanwhile, according to research in the journal Iga et al, (2012). The results of the research data analysis showed that the correlation value between self-control variables and the tendency of juvenile delinquency was -0.318 with a p of 0.000 . This shows that there is a significant negative correlation between the level of self-control and the tendency of juvenile delinquency. ${ }^{15}$ Yudha Henrika, (2017), concludes as follows: 1) the internal factors causing juvenile delinquency in Ampuan Kenagarian Lumpo Village, Pesisir Selatan Regency are in the fairly high category, meaning that internal factors are high enough to cause juvenile delinquency in Ampuan Kenagarian Lumpo Village, South Coast Regency. 2) external factors causing juvenile delinquency in Ampuan Kenagarian Lumpo Village, Pesisir Selatan Regency are in the fairly high category, meaning that external factors are high enough to cause juvenile delinquency in Ampuan Kenagarian Lumpo Village, Pesisir Selatan Regency. This research is recommended to Adolescents, Parents, Managers of Guidance and Counseling Study Programs, Self-Researchers, and Further Researchers. ${ }^{16}$ According to Sumara's research (2013), adolescents are the future assets of a nation. But nowadays a lot is happening to teenagers, such as drugs and motorcycle gangs. This is a familiar problem. Juvenile delinquency includes all behaviors that deviate from the norms of criminal law committed by juveniles. There are so many internal and external factors that cause juvenile delinquency that need to be considered. To overcome this, guidance from parents and also a good environment can be a determinant for the development of the teenager. ${ }^{17}$

Budi Artini, (2018), Based on the results of the study, it was found that the identity crisis factor did not affect as many as 9 respondents (56\%), the weak self-control factor did not affect as many as 10 respondents (63\%), the factor family/divorce did not affect 11 respondents (69\%), peer factors affected 9 respondents (56\%), and information and technology factors affected 8 respondents $(50 \%)$. Among these factors, the factor that most influenced juvenile delinquency in SMP A was the influence of peers as many as 9 respondents (56\%). This can be due to the fact that most of the respondents have a poor community. Therefore, to every parent, it is hoped that they will continue to control the community of their teenage children. ${ }^{18}$

Erieska Gita, (2017), There are several roles that parents can play in tackling juvenile delinquency, including; Parents must be an example of attitude and speech to their children, children's motivation, parents give direction with whom and in which community teenagers should hang out. Parents try to create a harmonious, communicative, and comfortable family for teenagers. as well as helping teenagers to choose good friends and good environment for teenagers. ${ }^{19}$ After seeing the results of several studies with similar titles, it is very likely that juvenile delinquency that occurred in the Panembong girang teenager was a failure in finding self-identity. As described in the research above. apart from the low level of education, thus making their knowledge and insight low, accompanied by a low economic level also makes the teenager feel that he does not have the achievements and potential he has, may also feel that he is meaningless, has no future and so on so that the compensation is the emergence of uncontrollable juvenile delinquency. By himself and by his parents. He doesn't care about himself, his family or the environment. Like the disease that occurs is already chronic and difficult to treat again. The government must intervene to handle all of this so that the impact that has occurred so far, namely the death of teenagers due to drinking alcohol does not happen again. Because teenagers as national assets must be saved from juvenile delinquency which has led to the realm of law. In addition to self-destruction, it is also disturbing for the surrounding community. Sometimes there is a fear that the teenager will influence other teens to binge drink. Because drunkenness is the source of evil, the source of evil must be eradicated. Because it can spread everywhere. Stealing, killing, raping, cheating and so on, are crimes that originate from drunkenness. Because he was drunk, there was no fear of going into people's homes, taking things. This has happened several times. Where there is an opportunity it must be done. The only way to prevent it from happening again is to eradicate alcohol from the roots. How can the teenager be diverted to other, more positive activities. Government programs such as Adolescent Reproductive Health Services (PKPR) need to be provided in Panembong Girang as adolescent reproductive health services such as counseling services and improving the ability of adolescents to apply education and healthy life skills (PKHS), by providing networks and integrated with cross-program, cross-sectoral, private organizations, and NGOs related to Youth Health. Because so far, researchers do not see any such program entering the village of Panembong rejoicing. It is very likely because there is no data so that the working area of the Nagrak Health Center does not know about these events. With the results of this study, the researchers hope that there will be a follow-up from the holders of the puskesmas area to foster youth with the PKPR program. PKPR can be implemented optimally if it provides a network and is integrated with cross programs, across sectors, private organizations, and NGOs related to adolescent health

according to the results of Helvy Yunida's research that Knowledge about Adolescents is obtained that most of the youth's skills are strong and some are very low. It can be assumed that most of the youth's skills are very good, only a small part is not good. So just apply every knowledge possessed by teenagers to be applied optimally. In the attitude/behavior variable, it can be interpreted that most of the attitude/behavior in the strong category and a small 
part in the very low category. This can It is assumed that teenagers already feel they have very good attitudes/behaviors. Hopefully with a very good perception of adolescents, make the teenager do good things about adolescent behavior both for himself and for the environment. ${ }^{20}$

\section{CONCLUSION}

The cause of the high death rate for adolescents in Panembong Girang Cianjur is due to the impact of juvenile delinquency that is not immediately addressed, namely teenagers drinking alcohol and accidents after drinking alcohol.

2. The lifestyle of teenagers in Panembong Girang Cianjur varies with several communities, including a community of parking attendants (likes to drink alcohol), a volleyball community and a youth community who goes to school and college.

\section{SUGGESTIONS}

1. Immediately, alcohol is eradicated to the roots, so that the death of a teenager due to drinking alcohol does not happen again

2. Panembong teenagers who are happy in the parking community or liquor drinkers, should be guided by the local government. Because he himself and his parents are no longer able to control.

3. The Nagrak Health Center provides guidance for youth with the PKPR . Program

\section{REFERENCES}

[1] Alek Gugi Gustaman, World Suicide Day 2020 RSJ Dr. Rajiman W. Lawang, http://rsjlawang>detail, 10 September 2021, East Java, 2020

[2] Budi Cahyono, 5 Teens Died after Drinking Oplosan Alcohol in Tangerang, Ayo Jakarta.com, Tuesday 25 August 2020.amp.ayojakarta.com, 2020

[3] Asep Caplin, 546 people died because of bootleg alcohol, CIPS: There must be access to legal alcoholic beverages 5 April 2019, Tribun Jabar, 2019

[4] Ira vera tika, Death toll Illegal alcohol in Bandung is higher than the national average, thought-rakyat.com, Bandung, May 5 2018, http://www.tangan-rakyat.com, 2018

[5] Pusdatin, infodatin about reproduction Pusdatin Kemenkes RI, definition of adolescents according to WHO, http://pusdatin,kemkes.go.id, ISSN:2442-7659, 2013

[6] Sugiyono), Administrative research methods, ISBN: 979:8433-02-3, Alfabeta Bandung, 2003

[7] Sukandarrumidi, (Research method: Practical Guide for Researchers, Yogyakarta: Gajah Mada University Press, 2006).

[8] Sugiyono, Qualitative Research Methods, ISBN: 978-602-289-373-8, 2nd edition, 2019

[9] Setiawan A Saryono, Midwifery Research Methods D III, D IV, S1, and S2, Nuha Medika, 3rd printing, October 2011, ISBN: 978-979-1446-72-3, email: nuhamedika@gmail .com-nuhamedika@yahoo.com, http://www.nuhamedika.gu,ma, (2011)

[10]Notoatmodjo and Soekidjo, health promotion and behavioral science, Jakarta, 2009

[11]Agus warsudi, Cianjur Police revealed case of roso-roso mixed alcohol, Friday, November 13, 2020.jabar.news.jabar.id, 2020

[12] Liputan 6.com,(2015), Three people in Cianjur died from bootleg liquor, May 3, 2015 at 22:48 WIB

[13]Iga Serpianing Aroma, Dewi Retno, Suminar, Relationship Between Level of Self-Control and Tendency of Juvenile Delinquency, Faculty of Psychology Universitas Airlangga Surabaya, Journal of Educational and $\begin{array}{lllllll}\text { Developmental } & \text { Psychology } & \text { Vol. } & \text { No. June 2012, }\end{array}$ http://www.journal.unair.ac.id/filerPDF/110810241_ringkasan.pdf, 2012

[14]Suci Prasasti,(2017), Juvenile Delinquency and Its Causes, Proceedings of SNBK National Seminar on Guidance and Counseling, Vol 1, No 1 (2017) > Inscription, http://prosiding.unipma.ac.id/index.php /SNBK/article/view/110, 2017

[15]Bamandhita Rahma Setiaji \& Tania Savitri, 5 of the most common causes of death in adolescents worldwide, hello healthy, 7 September 2020, 2020

[16] Yudha Henrika, Factors Causing Juvenile Delinquency (Descriptive Study on Adolescents in Ampuan Village, Kenagarian Lumpo, Pesisir Selatan Regency). 2017

[17]Dadan Sumara, Sahadi Humaedi \& Meilani Budiarti Santoso, (2017), Juvenile delinquency and its handlers, Proceedings of research and community service, ISSN online: 25811126, DOI: https://doi.org/10.24198/jppm.v4i2. 14393, vol 4 no.2

[18]Budi Artini, Analysis of Factors Influencing Juvenile Delinquency, DOI: https://doi.org/10.47560/kep.v7i1.117 , Vol 7 No 1 (2018): Journal of Nursing / 2018 
International Journal of Social Science (IJSS)

Vol.1 No.3 October 2021, pp:151-158

ISSN: ISSN: 2798-3463 (Printed) | 2798-4079 (Online)

DOI: $\underline{\text { https://doi.org/10.53625/ijss.v1i3.407 }}$

[19] Erieska Gita Lestari, Sahadi Humaedi, e all, The Role of Families in Overcoming Juvenile Delinquency, Research and Community Service Proceedings, ISSN Online: 2581-11, 2017

[20] Helvy Yunida, Overview of Adolescent Reproductive Health in Panembong Girang, Mekarsari Village, Cianjur, Jartika (Sinta), Journal of Technology Research and Educational Innovation 3(2):382-387, DOI: 10.36765/jartika.v3i2.310, July 2020. 2020 
